\title{
EFFECTS OF PENDIMETHALIN ON POD ATTRIBUTES OF FIVE ELITE ACCESSIONS OF COWPEA
}

\author{
DJELOVANJE PENDIMETHALINA NA DIJELOVE MAHUNE \\ PET ELITNIH VRSTA STOČNOG GRAŠKA
}

\section{Oladele Justina Olujuwon, Animasaun David Adedayo, Oyedeji Stephen, Adekola Olabisi Fatimoh, Olorunmaiye Kehinde Stephen}

\begin{abstract}
A field study on the effects of pre- and post-emergence application of herbicide (pendimethalin) on the reproductive yield of five accessions of cowpea (TVu-9092, TVu-16265, TVu-16320, TVu-16323 and TVu-16421) was conducted between June and August, 2018. Pendimethalin was applied both as pre- and early post-emergence herbicide (PE and EPOE) and followed by hand weeding at 4 and 8 weeks after sowing (WAS). Number of pods per plant was highest in TVu-9092 treated with $0.125 \mathrm{~kg} / \mathrm{ha} \mathrm{PE}$ pendimethalin (19.33) and $0.250 \mathrm{~kg} / \mathrm{ha}$ pendimethalin EPOE application (19.00). Highest pod diameter in PE treatment was produced in TVu-16320 with $0.25 \mathrm{~kg} /$ ha pendimethalin $(7.55 \mathrm{~mm})$ and $\mathrm{TVu}-16323$ with $0.125 \mathrm{~kg} / \mathrm{ha}$ pendimethalin produced the highest pod diameter $(7.74 \mathrm{~mm})$ in the EPOE treatment. Highest pod length in the PE treatment was produced in TVu-9092 with $0.125 \mathrm{~kg} / \mathrm{ha}$, while TVu-9092 without pendimethalin produced the highest pod length $(30.00 \mathrm{~cm})$ in the EPOE treatment. In the PE treatment, TVu-16265 and TVu-9092 treated with $0.125 \mathrm{~kg} / \mathrm{ha}$ had the highest $(2.99 \mathrm{~g})$ and lowest empty pod weights $(1.70 \mathrm{~g})$ respectively. In the EPOE treatment, the highest empty pod weight $(3.01 \mathrm{~g})$ was produced in $\mathrm{TVu}-16265$ with $0.125 \mathrm{~kg} / \mathrm{ha}$ pendimethalin while the control of $\mathrm{TVu}-16320$ recorded the lowest empty pod weight $(2.03 \mathrm{~g})$. The highest of 100 seeds weight $(14.91 \mathrm{~g})$ was produced in TVu-16421 with $0.125 \mathrm{~kg} / \mathrm{ha}$ pendimethalin PE treatment and lowest $(9.26 \mathrm{~g})$ was obtained in the untreated control of TVu-16323. In the post-emergence treatment, the lowest 100 seeds weight $(8.88 \mathrm{~g})$ was obtained in TVu-16320 with $0.125 \mathrm{~kg} / \mathrm{ha}$. Highest weight per pod in the PE and EPOE application was obtained in untreated control with TVu-9092 (10.47 g), while the lowest weight per pod $(3.22 \mathrm{~g})$ was in TVu-16265 with $0.125 \mathrm{~kg} / \mathrm{ha}$ EPOE application. The study
\end{abstract}


Oladele Justina Olujuwon et al.: Effects of pendimethalin on pod attributes of five elite accessions of cowpea

concluded that pendimethalin application as pre- and early post-emergence herbicide at low and high concentrations produced varying effects on pod attributes among the accessions of cowpea.

Key words: herbicide, leaves, pod, pod length, pod weight, seed per pod

\section{SAŽETAK}

Terensko istraživanje primjene herbicida (pendimethalina) prije i poslije klijanja na reproduktivni prinos pet vrsta stočnog graška (TVu-9092, TVu-16265, TVu-16320, TVu-16323 i TVu-16421, provedeno je između lipnja i kolovoza 2018. godine. Penthalin je primijenjen kao herbicid prije i poslije klijanja (PE i EPOE) nakon čega je slijedilo ručno pljevljenje 4 i 8 tjedana nakon sijanja (WAS). Broj mahuna po biljci bio je najveći kod TVu-9092 tretiranog sa $0,125 \mathrm{~kg} / \mathrm{ha}$ PE pendimethalina $(19,33)$ i $0,250 \mathrm{~kg} / \mathrm{ha}$ pendimethalina EPOE $(19,00)$. Najviši promjer mahune u PE tretmanu nastao je u TVu-16320 s 0,25 kg/ha pendimetalina $(7,55 \mathrm{~mm})$, a TVu-16323 s $0,125 \mathrm{~kg} / \mathrm{ha}$ pendimetalina proizveo je najveći promjer mahune $(7,74 \mathrm{~mm})$ $\mathrm{u}$ tretmanu EPOE. Najveća duljina mahuna u PE obradi proizvedena je u TVu-9092 s 0,125 kg/ha, dok je TVu-9092 bez pendimetalina proizvela najveću duljinu mahune $(30,00 \mathrm{~cm})$ u EPOE tretmanu. U PE postupku TVu-16265 i TVu-9092 sa $0,125 \mathrm{~kg} / \mathrm{ha}$ imao najviše $(2,99 \mathrm{~g})$ i najniže težine prazne mahune $(1,70 \mathrm{~g})$. U EPOE postupku najveću težinu prazne mahune $(3,01 \mathrm{~g})$ imao je TVu-16265 sa $0,125 \mathrm{~kg} / \mathrm{ha}$ pendimethalina dok je kontrola TVu-16320 zabilježila najnižu težinu prazne mahune $(2,03 \mathrm{~g})$. Najveća težina 100 sjemenki $(14,91$ g) zabilježena je u TVu-16421 sa $0,125 \mathrm{~kg} / \mathrm{ha}$ pendimethalina dok je kontrola $\mathrm{TVu}-1632$ zabilježila najnižu težinu prazne mahune $(2,03 \mathrm{~g})$. Najviša težina sto sjemenki $(14,91 \mathrm{~g})$ proizvedena je u TVu-16421 sa $0,125 \mathrm{~kg} /$ ha pedimenthalina i najniža $(9,26 \mathrm{~g})$ u netretiranoj kontroli TVu-16323. U postupku nakon klijanja najniža težina 100 sjemenki $(8,88 \mathrm{~g})$ zabilježena je u TVu-16320 najniža težina prazne mahune $(2,03 \mathrm{~g})$. Najviša težina 100 sjemenki u postupku PE i EPOE dobivena je u netretiranoj kontroli sa TVu-9092 $(10,47 \mathrm{~g})$ dok je najniža težina po mahuni $(3,22 \mathrm{~g})$ bila kod TVu-16265 sa $0,125 \mathrm{~kg} / \mathrm{ha}$ EPOE. U radu je zaključeno da je primjena pedimenthalina prije i odmah poslije klijanja u niskim i visokim koncentracijama imala različito djelovanje na mahunu raznih vrsta stočnog graška.

Ključne riječi: herbicid, listovi, mahuna, duljina mahune, težina mahune, sjeme po mahuni 
Oladele Justina Olujuwon et al.: Effects of pendimethalin on pod attributes of five elite accessions of cowpea

\section{INTRODUCTION}

Cowpea, Vigna unguiculata (L.) Walp, is one of the most important grain legumes in many countries of the tropics, particularly Asia and Africa (Asiwe et al., 2009; Osipitan, 2017). Cowpea has been described as the most important crops to the livelihoods of millions of relatively poor people in less developed countries of the tropics (FAO, 2012) and it was regarded as the most economically important indigenous African leguminous crop (Ugbe et al., 2016). Globally, an estimated 3.7 million metric tonnes of cowpea is produced annually on about 8.7 million hectares (Langyintuo et al., 2003). Africa accounted for about $87 \%$ of annual cowpea production, America for $10 \%$ while Europe and Asia for the rest (Ugbe et al., 2016). Cowpea is a major source of plant protein in Nigeria and most other African countries as the grains contain about $25 \%$ protein, and several vitamins and minerals (Mbata et al., 2000). In many parts of the world, cowpea served as fodder for many animals.

Despite many importance of cowpea, its yield is generally low as a result of some factors such as diseases and pests, drought, insect pest and weeds (Gungula and Garjila, 2005). Weeds constitute the most important constraints that influence cowpea production in the tropics (Keramati et al., 2008) as it competes with crops, reduce their growth rate, quantity and quality of grain yield as well as increase the cost of production (Akobundu, 1987). In fact, yield reductions of $13-82 \%$ have been reported in cowpea due to weed competition (Li et al., 2004; Tripathi and Singh, 2001). Also, Muhammad et al. (2003) reported that, weed competition with cowpea reduced yield by $82 \%$ and a significant increase pods yield was recorded by controlling weeds up to 45 days of sowing. Cowpea yield can be as low as $110 \mathrm{~kg} / \mathrm{ha}$ on weedy farmers' fields in northern guinea savanna of Nigeria which is the heart of its growing region in West and Central Africa (Oyekanmi and Sangodoyin, 2007). A timely weed removal at the critical period, which falls within the first 40 days of cowpea growth, would help to prevent yield loss (Osipitan, 2017). Therefore, in order to enhance crop yield, weed control during this period is very important.

Physical and mechanical approaches of weed control are very expensive (Khan et al., 2004), due to high cost of labour, logistic problem or limited availability of labour. Thus, on medium to large scale cropping, chemical weed control seems to be easiest form of controlling weed as it is more convenient, faster and reduce labour cost. The advantage of herbicides in increasing yield of crops and reducing labour cost is said to be of great importance to farmers in Nigeria (Melifonwu, 1992). 
Oladele Justina Olujuwon et al.: Effects of pendimethalin on pod attributes of five elite accessions of cowpea

According to Patel et al. (2003), significantly higher grain yield and net return of cowpea were obtained with pre-emergence application of (Pendimethalin at $0.75 \mathrm{~kg} \mathrm{ha}^{-1}$ plus weeding at 5 weeks after planting) compared to other treatments. Also, Singh et al. (2004) reported that application of herbicide and hand weeding (Pendimethalin at $1.0 \mathrm{~kg} \mathrm{ha}^{-1}$ plus hand weeding at 30 days after planting) produced significantly higher cowpea grain yield and reduced weed density and biomass. The use of herbicides may therefore provide a timely and adequate alternative to hand weeding as this not only removes the drudgery associated with it but also lowers the cost of weeding and provides protection for crop against early weed competition when pre-emergence herbicides are used (Akobundu, 1987). Nonetheless, cowpea is believed to be more sensitive to herbicides than other leguminous species. Therefore, it is important to investigate the effects of pendimethalin herbicide on the yield components of cowpea. Thus, this study assessed the effect of pendimethalin on the reproductive yield and seed related traits of five elite varieties of cowpea from the germplasm of International Institute for Tropical Agriculture, Nigeria.

\section{MATERIALS AND METHODS}

\section{Description of experimental site}

The experiment was conducted at the Botanical garden of the Department of Plant Biology, University of Ilorin, Kwara State, Nigeria, during the rainy season between June and August 2018. University of Ilorin is located in guinea savanna agro-ecological zone of Nigeria on latitude $8^{0} 24^{\prime} \mathrm{N}$ and $8^{0} 36^{\prime} \mathrm{N}$ and longitude $4^{0} 10^{\prime} \mathrm{E}$ and $4^{0} 36^{\prime} \mathrm{E}$. The climate is tropical with average annual temperature of $26.5^{\circ} \mathrm{C}$ and rainfall of $1217 \mathrm{~mm}$ (World Site Atlas, 2018).

\section{Experimental layout, land preparation and germplasm collection}

The land used for the experiment was cleared and ridges were prepared manually using hand hoe. The treatments were allotted in a randomized block design (RBD). Five elite accessions of cowpea (TVu-9092, TVu-16265, TVu-16320, TVu-16323 and TVu-16421) from germplasm of the International Institute for Tropical Agriculture (IITA), Ibadan, Oyo State, Nigeria were used for the study.

TVu-9092 is a member of TVu-9 accessions (cultivar C3) collected in 1971 from the Ministry of Agriculture and Natural Resources (MANR), Nigeria by IITA. The growth habit of TVu-9092 accession is semi-prostrate with the main 
Oladele Justina Olujuwon et al.: Effects of pendimethalin on pod attributes of five elite accessions of cowpea

stem at $20 \mathrm{~cm}$ or more above the ground and the branches spreading 1 to $4 \mathrm{~m}$. The accession is resistant to Cercospora canescens leaf spot disease, bacterial blight and target spot diseases (IITA, 2021a). TVu-16265, TVu-16320, TVu-16323 and TVu-16421 are among TVu-16 series (cultivar C-1968) of IITA. The accessions are among the over 300 traditional cultivars of cowpea collected by IITA from MANR in 1971. The growth habit is erect (about $37.5 \mathrm{~cm}$ tall) with the branches forming acute angle with the main stem. The accessions are also resistant to leaf spot diseases of $C$. canescens and C. cruenta, bacterial blight, target spot and rust (IITA, 2021b).

\section{Treatment application and assessment of its effects}

Pendimethalin (herbicide) was applied as pre-emergence (PE) immediately after sowing at planting and as post-emergence (EPOE) at 10 days after emergence, followed by two hand weeding at 4 and 8 WAS. Two concentrations $(0.125$ and $0.250 \mathrm{~kg} / \mathrm{ha})$ of the herbicide were used. Sowing was done by direct manual sowing, at a depth of $5 \mathrm{~cm}$, and one seed per position (hole). The pre-emergence (PE) herbicide was applied immediately after the seeds were sown while the early post emergence (EPOE) herbicide treatment was applied 10 days after emergence of the seedling. Using 25-Litre knap-sack sprayer. Watering was carried out at an interval of 2-3 days as required when there was no rain. The reproductive parameters were taken at maturity. Each treatment was replicated three times without any treatment allotted to the control plots which were left weedy throughout the period of the experiment.

\section{Data collection and Analysis}

Sampling was done at 2 weeks' interval after germination of the crop. Three plants were randomly selected from each treatment per plot for the study. At harvest, data were collected on pod diameter, pod length, number of seed per pod, weight of pod, weight of 100 seeds and weight of empty pods (a feed source for livestock). The data collected from the study were analyzed by analysis of variance (ANOVA) using statistical package for social sciences (SPSS: version 16.0). The means were separated by Duncan Multiple Range Test (DMRT) at $(\mathrm{P}<0.05)$.

\section{RESULTS AND DISCUSSION}

In PE pendimethalin application, As seen in Table (1) the number of pods per plant in the pre-emergence (PE) treatment was highest in TVu-9092 treated with $0.125 \mathrm{~kg} / \mathrm{ha}$ pendimethalin (19.33) and lowest in TVu-16323 
Oladele Justina Olujuwon et al.: Effects of pendimethalin on pod attributes of five elite accessions of cowpea

with $0.250 \mathrm{~kg} /$ ha pendimethalin (13.00). In the early post-emergence (EPOE) treatment, TVu-9092 treated with $0.250 \mathrm{~kg} / \mathrm{ha}$ pendimethalin and $\mathrm{TVu}-16320$ control plants had the highest number of pods (19.00).

In the PE treatment, TVu-16320 treated with $0.25 \mathrm{~kg} / \mathrm{ha}$ of pendimethalin recorded the highest pod diameter $(7.55 \mathrm{~mm})$ and was significantly different from the other treatments $(\mathrm{P}<0.05)$. The TVu-9092 control plant and those treated with $0.125 \mathrm{~kg} / \mathrm{ha}$ of pendimethalin; $\mathrm{TVu}-16265$ control plant and those treated with 0.125 and $0.25 \mathrm{~kg} / \mathrm{ha}$ of pendimethalin; TVu- 16320 control plant; TVu-16323 control plant and TVu-16421 treated with $0.125 \mathrm{~kg} / \mathrm{ha}$ of pendimethalin recorded pod diameter values that were not significantly different $(\mathrm{P}<0.05)$. The least pod diameter was recorded by $\mathrm{TVu}-16421$ treated with $0.25 \mathrm{~kg} / \mathrm{ha}$ of pendimethalin $(5.97 \mathrm{~mm})$. Meanwhile in EPOE pendimethalin application, the highest and lowest pod diameters were recorded in TVu-16323 treated with $0.125 \mathrm{~kg} / \mathrm{ha}$ of pendimethalin $(7.74 \mathrm{~mm})$ and TVu-9092 treated with 0.125 and $0.25 \mathrm{~kg} / \mathrm{ha}$ of pendimethalin respectively.

In PE pendimethalin $(6.21 \mathrm{~mm})$ application, there was no significant difference between pod lengths of TVu-9092 control plant and those treated with 0.125 and $0.25 \mathrm{~kg} / \mathrm{ha}(\mathrm{P}<0.05)$ (Tables 1$)$. However, those treated with $0.125 \mathrm{~kg} / \mathrm{ha}$ recorded the highest pod length. The trend of the effect was similar for the EPOE pendimethalin application. The pod length of TVu-9092 (control plant) and those of the accession treated with 0.125 and $0.25 \mathrm{~kg} / \mathrm{ha}$ of pendimethalin did not show significant difference $(\mathrm{P}<0.05)$. Nevertheless, the control plant had the highest pod length. Reduction in pod length for preemergent (PE) application of pendimethalin as compared to post-emergent (EPOE) pendimethalin application corroborated the findings of Ademiluyi and Joseph (2016) who reported a reduction in pod length of cowpea when pendimethalin was applied as post-emergent herbicide. Moreover, Makinwa and Akinyemiju (1990) had earlier demonstrated that applying the herbicide at this stage could effectively suppress the weeds and may be better tolerated by the cowpea which may result into better performance in terms of yield components.

For the PE pendimethalin application, although number of seed per pod was highest (19.33) in TVu-9092 treated with $0.125 \mathrm{~kg} / \mathrm{ha}$, it was not significantly different $(\mathrm{P}<0.05)$ from the seed yield of the control and $\mathrm{TVu}-16320$ treated with $0.125 \mathrm{~kg} / \mathrm{ha}$ (Table 1). The result further showed that EPOE pendimethalin application at $0.25 \mathrm{~kg} / \mathrm{ha}$ favoured number of seed/pod with the highest recorded for TVu-16320. However, it was not significantly different from TVu-9092 control plant and those treated with $0.125 \mathrm{~kg} / \mathrm{ha}$, and TVu-16320 treated with 0.125 and $0.25 \mathrm{~kg} / \mathrm{ha}$ of pendimethalin which had 17.33, 18.33, 
Oladele Justina Olujuwon et al.: Effects of pendimethalin on pod attributes of five elite accessions of cowpea

18.00 and $17.33 \mathrm{seed} /$ pod respectively. The present result was in congruence to the report of Ademiluyi and Joseph (2016) who elucidated that a higher number of seeds per pod were produced in cowpea when pendimethalin was sprayed as pre-emergent herbicide rather than post-emergent. These results demonstrated that better yield performances could be obtained in cowpea plots where pendimethalin herbicide was applied at pre-emergent level. This observation was further affirmed and attributed to lower phytotoxicity of pemdimethalin to cowpea when applied as pre-emergent herbicide rather than post-emergent herbicide, resulting in higher number of seeds per pod (Costa et al., 2017).

Table 1 Effect of pendimethalin application on pod attributes of five elite cowpea accessions. PE - pre-emergence pendimethalin application, EPOE - early post-emergence pendimethalin application, values are means and those with similar letter(s) in a column are not significantly different at $(\mathrm{P}<0.05)$ level.

Tablica 1. Učinak primjene pendimetalina na dijelove mahuna pet elitnih vrsta stočnog graška. PE - primjena pendimetalina prije nicanja, EPOE - rana primjena pendimetalina nakon nicanja, $(\mathrm{P}<\mathbf{0 , 0 5})$.

\begin{tabular}{|c|c|c|c|c|c|c|}
\hline \multirow{2}{*}{ Variety/Concentration } & \multicolumn{2}{|c|}{ Number of pod/plant } & \multicolumn{2}{|c|}{ Pod diameter (mm) } & \multicolumn{2}{|c|}{ Pod length $(\mathrm{cm})$} \\
\hline & $\mathrm{PE}$ & EPOE & PE & EPOE & $\mathrm{PE}$ & EPOE \\
\hline \multicolumn{7}{|l|}{ TVu-9092 } \\
\hline Control & $17.33^{\mathrm{ab}}$ & $17.33^{\mathrm{ab}}$ & $6.49^{\mathrm{abc}}$ & $6.49^{\mathrm{bc}}$ & $30.00^{\mathrm{a}}$ & $30.00^{\mathrm{a}}$ \\
\hline $0.125 \mathrm{~kg} / \mathrm{ha}$ & $19.33^{\mathrm{a}}$ & $18.33^{\mathrm{a}}$ & $6.92^{\mathrm{abc}}$ & $6.21^{\mathrm{c}}$ & $31.00^{\mathrm{a}}$ & $27.67^{\mathrm{a}}$ \\
\hline $0.250 \mathrm{~kg} / \mathrm{ka}$ & $17.00^{\mathrm{abc}}$ & $19.00^{\mathrm{a}}$ & $6.22^{\mathrm{bc}}$ & $6.21^{\mathrm{c}}$ & $28.67^{\mathrm{a}}$ & $28.67^{\mathrm{a}}$ \\
\hline \multicolumn{7}{|l|}{ TVu-16265 } \\
\hline Control & $14.67^{\text {cd }}$ & $14.67^{\text {cd }}$ & $6.63^{\mathrm{abc}}$ & $6.63^{\mathrm{bc}}$ & $17.00^{\mathrm{d}}$ & $17.00^{\mathrm{d}}$ \\
\hline $0.125 \mathrm{~kg} / \mathrm{ha}$ & $15.00^{\text {bcd }}$ & $15.00^{\text {cd }}$ & $6.70^{\mathrm{abc}}$ & $7.01^{\mathrm{abc}}$ & $18.67^{\mathrm{d}}$ & $17.67^{\mathrm{d}}$ \\
\hline $0.250 \mathrm{~kg} / \mathrm{ka}$ & $14.33^{\mathrm{d}}$ & $16.00^{\mathrm{bc}}$ & $6.49^{\mathrm{abc}}$ & $7.33^{\mathrm{ab}}$ & $17.50^{\mathrm{d}}$ & $18.17^{\mathrm{d}}$ \\
\hline \multicolumn{7}{|l|}{ TVu-16320 } \\
\hline Control & $19.00^{\mathrm{a}}$ & $19.00^{\mathrm{a}}$ & $6.77^{\mathrm{abc}}$ & $6.77^{\mathrm{abc}}$ & $25.00^{\mathrm{b}}$ & $25.00^{\mathrm{b}}$ \\
\hline $0.125 \mathrm{~kg} / \mathrm{ha}$ & $18.33^{\mathrm{a}}$ & $18.00^{\mathrm{a}}$ & $7.21^{\mathrm{ab}}$ & $7.11^{\mathrm{abc}}$ & $22.00^{\mathrm{c}}$ & $23.67^{\mathrm{b}}$ \\
\hline $0.250 \mathrm{~kg} / \mathrm{ka}$ & $18.00^{\mathrm{a}}$ & $17.33^{\mathrm{ab}}$ & $7.55^{\mathrm{a}}$ & $6.76^{\mathrm{abc}}$ & $23.67^{\mathrm{bc}}$ & $21.17^{\mathrm{c}}$ \\
\hline \multicolumn{7}{|l|}{ TVu-16323 } \\
\hline Control & $15.33^{\mathrm{bcd}}$ & $15.33^{\text {cd }}$ & $6.483^{\mathrm{abc}}$ & $6.48^{\mathrm{bc}}$ & $16.33^{\mathrm{d}}$ & $16.33^{d}$ \\
\hline $0.125 \mathrm{~kg} / \mathrm{ha}$ & $15.33^{\mathrm{bcd}}$ & $15.00^{\text {cd }}$ & $7.14^{\mathrm{ab}}$ & $7.74^{\mathrm{a}}$ & $16.67^{\mathrm{d}}$ & $17.00^{\mathrm{d}}$ \\
\hline $0.250 \mathrm{~kg} / \mathrm{ka}$ & $13.00^{\mathrm{d}}$ & $15.00^{\mathrm{cd}}$ & $7.26^{\mathrm{ab}}$ & $7.00^{\mathrm{abc}}$ & $17.33^{\mathrm{d}}$ & $17.33^{\mathrm{d}}$ \\
\hline \multicolumn{7}{|l|}{ TVu-16421 } \\
\hline Control & $14.67^{\text {cd }}$ & $14.67^{\text {cd }}$ & $7.22^{\mathrm{ab}}$ & $7.22^{\mathrm{abc}}$ & $18.00^{\mathrm{d}}$ & $18.00^{\mathrm{d}}$ \\
\hline $0.125 \mathrm{~kg} / \mathrm{ha}$ & $13.67^{\mathrm{d}}$ & $13.67^{\mathrm{d}}$ & $6.81^{\mathrm{abc}}$ & $6.97^{\mathrm{abc}}$ & $17.00^{\mathrm{d}}$ & $17.50^{\mathrm{d}}$ \\
\hline $0.250 \mathrm{~kg} / \mathrm{ka}$ & $15.00^{\mathrm{bcd}}$ & $15.00^{\text {cd }}$ & $5.97^{\mathrm{c}}$ & $6.52^{\mathrm{bc}}$ & $18.00^{\mathrm{d}}$ & $18.67^{\mathrm{d}}$ \\
\hline
\end{tabular}


Oladele Justina Olujuwon et al.: Effects of pendimethalin on pod attributes of five elite accessions of cowpea

In term of pod weight, highest and lowest pod weights were recorded by TVu-16265 treated with $0.125 \mathrm{~kg} / \mathrm{ha}$ and $\mathrm{TVu}-16320$ treated with $0.25 \mathrm{~kg} / \mathrm{ha}$ of PE pendimethalin $(2.99 \mathrm{~g}$ and $1.91 \mathrm{~g})$ respectively (Table 2). This trend was similar for the EPOE pendimethalin application. However, TVu-16320 of the untreated plot produced the least pod weight $(2.03 \mathrm{~g})$. In tandem with this, Ademiluyi and Joseph (2016) reported a higher weight of pod when pendimethalin was sprayed as pre-emergent herbicide rather than post-emergent.

The highest weights of 100 seeds were produced in TVu-16421 when pendimethalin was applied at PE and EPOE (14.07 and $14.36 \mathrm{~g}$ ). The lowest weight of 100 seeds was recorded in variety TVu-16323 control $(9.26 \mathrm{~g})$ when pendimethalin was applied as PE herbicide. However, with application of pendimethalin at EPOE, the lowest weight of 100 seeds occurred in TVu-16320 with $0.125 \mathrm{~kg} / \mathrm{ha}$ pendimethalin concentration $(8.88 \mathrm{~g})$. This observation suggests that the application of pendimethalin herbicide did not result in lethal effect on the cowpea which was in accordance with earlier report by Oluwafemi and Abiodun (2016) who studied the comparative evaluation of hoe-weeding and pendimethalin on weed management in cowpea.

Furthermore, application of pendimethalin as PE and EPOE herbicide resulted in highest empty pod weight in TVu-9092 control plants (10.47 g) (Table 2). Empty pods of legumes such as peas and cowpeas are fed to animals (Wadhwa and Bakshi, 2013; Wadhwa et al., 2017), mulching and biomass fuel. The lowest weights of empty pod when pendimethalin was applied as pre- and post-emergence were recorded by TVu- 16320 treated with $0.25 \mathrm{~kg} / \mathrm{ha}$ of pendimethalin and $\mathrm{TVu}-16265$ treated with $0.125 \mathrm{~kg} / \mathrm{ha}$ of pendimethalin (4.49 and $3.32 \mathrm{~g}$ ) respectively. TVu-9092 showed varietal advantage over other accessions by recording low weights of empty pods when pendimethalin was applied as PE and EPOE herbicides. This finding is in consonance with earlier report by Choudhary et al. (2013) who studied the response of cowpea to fertility levels and mulching and many other workers (Chinnusamy et al., 2010; Hussaini and Lado, 2010) who had earlier investigated the effects of chemical herbicides and their concentrations on performance and yield of cowpea. 
Oladele Justina Olujuwon et al.: Effects of pendimethalin on pod attributes of five elite accessions of cowpea

Table 2 Effect of pendimethalin application on pod and weights (g) of five elite cowpea accessions. PE - pre-emergence pendimethalin application, EPOE - early postemergence pendimethalin application, values are means and those with similar letter(s) in a column are not significantly different at $(\mathbf{P}<0.05)$ level.

Tablica 2. Učinak primjene pendimetalina na težinu mahune (g) pet elitnih vrsta stočnog graška. PE - primjena pendimetalina prije nicanja, EPOE - rana primjena pendimetalina nakon nicanja, $(\mathbf{P}<0.05)$

\begin{tabular}{|c|c|c|c|c|c|c|}
\hline \multirow{2}{*}{$\begin{array}{c}\text { Variety/ } \\
\text { Concentration }\end{array}$} & \multicolumn{2}{|c|}{ Weight of pod (g) } & \multicolumn{2}{|c|}{ Weight of 100 seeds $(\mathrm{g})$} & \multicolumn{2}{|c|}{ Weight of empty pods (g) } \\
\hline & PE & EPOE & E & EPOE & $\mathrm{PE}$ & EPOE \\
\hline \multicolumn{7}{|l|}{ TVu-9092 } \\
\hline Control & $10.47^{\mathrm{a}}$ & $10.47^{\mathrm{a}}$ & $9.57^{\mathrm{b}}$ & $9.57^{\mathrm{cd}}$ & $2.27^{\mathrm{bcd}}$ & $2.27^{\mathrm{ab}}$ \\
\hline $0.125 \mathrm{~kg} / \mathrm{ha}$ & $7.84^{\mathrm{ab}}$ & $7.88^{\mathrm{abc}}$ & $10.34^{\mathrm{b}}$ & $9.69^{\mathrm{cd}}$ & $1.70^{\mathrm{ab}}$ & $2.63^{\mathrm{ab}}$ \\
\hline $0.250 \mathrm{~kg} / \mathrm{ka}$ & $8.50^{\mathrm{ab}}$ & $7.75^{\mathrm{abc}}$ & $9.87^{\mathrm{b}}$ & $11.13^{\mathrm{bc}}$ & $2.68^{\mathrm{ab}}$ & $2.37^{\mathrm{ab}}$ \\
\hline \multicolumn{7}{|l|}{ TVu-16265 } \\
\hline Control & $9.20^{\mathrm{ab}}$ & $9.20^{\mathrm{ab}}$ & $12.89^{\mathrm{a}}$ & $12.89^{\mathrm{ab}}$ & $2.51^{\mathrm{abc}}$ & $2.51^{\mathrm{ab}}$ \\
\hline $0.125 \mathrm{~kg} / \mathrm{ha}$ & $8.40^{\mathrm{ab}}$ & $3.32^{\mathrm{c}}$ & $13.66^{\mathrm{a}}$ & $14.03^{\mathrm{a}}$ & $2.99^{\mathrm{a}}$ & $3.01^{\mathrm{a}}$ \\
\hline $0.250 \mathrm{~kg} / \mathrm{ka}$ & $4.69^{\mathrm{b}}$ & $5.60^{\mathrm{abc}}$ & $13.93^{\mathrm{a}}$ & $14.62^{\mathrm{a}}$ & $2.73^{\mathrm{ab}}$ & $2.37^{\mathrm{ab}}$ \\
\hline \multicolumn{7}{|l|}{ TVu-16320 } \\
\hline Control & $5.48^{\mathrm{b}}$ & $5.48^{\mathrm{bc}}$ & $13.11^{\mathrm{a}}$ & $13.11^{\mathrm{a}}$ & $2.03^{\mathrm{cd}}$ & $2.03^{\mathrm{b}}$ \\
\hline $0.125 \mathrm{~kg} / \mathrm{ha}$ & $5.41^{\mathrm{b}}$ & $4.58^{\mathrm{bc}}$ & $10.14^{\mathrm{b}}$ & $8.88^{\mathrm{d}}$ & $2.03^{\mathrm{cd}}$ & $2.53^{\mathrm{ab}}$ \\
\hline $0.250 \mathrm{~kg} / \mathrm{ka}$ & $4.69^{\mathrm{b}}$ & $3.61^{\mathrm{c}}$ & $9.27^{\mathrm{b}}$ & $8.98^{\mathrm{d}}$ & $1.91^{\mathrm{d}}$ & $2.17^{\mathrm{b}}$ \\
\hline \multicolumn{7}{|l|}{ TVu-16323 } \\
\hline Control & $5.21^{\mathrm{b}}$ & $5.21^{\mathrm{bc}}$ & $9.26^{\mathrm{b}}$ & $9.62^{\mathrm{cd}}$ & $2.53^{\mathrm{ab}}$ & $2.53^{\mathrm{ab}}$ \\
\hline $0.125 \mathrm{~kg} / \mathrm{ha}$ & $6.07^{\mathrm{ab}}$ & $4.81^{\mathrm{bc}}$ & $14.72^{\mathrm{a}}$ & $14.09^{\mathrm{a}}$ & $2.37^{\mathrm{bcd}}$ & $2.60^{\mathrm{ab}}$ \\
\hline $0.250 \mathrm{~kg} / \mathrm{ka}$ & $4.49^{\mathrm{b}}$ & $6.48^{\mathrm{abc}}$ & $13.92^{\mathrm{a}}$ & $13.40^{\mathrm{a}}$ & $2.63^{\mathrm{ab}}$ & $2.63^{\mathrm{ab}}$ \\
\hline \multicolumn{7}{|l|}{ TVu-16421 } \\
\hline Control & $6.58^{\mathrm{ab}}$ & $6.58^{\mathrm{abc}}$ & $14.29^{\mathrm{a}}$ & $14.29^{\mathrm{a}}$ & $2.39^{\mathrm{bcd}}$ & $2.39^{\mathrm{ab}}$ \\
\hline $0.125 \mathrm{~kg} / \mathrm{ha}$ & $5.83^{b}$ & $4.76^{\mathrm{bc}}$ & $14.91^{\mathrm{a}}$ & $13.86^{\mathrm{a}}$ & $2.69^{\mathrm{ab}}$ & $2.44^{\mathrm{ab}}$ \\
\hline $0.250 \mathrm{~kg} / \mathrm{ka}$ & $6.74^{\mathrm{ab}}$ & $9.25^{\mathrm{ab}}$ & $14.07^{\mathrm{a}}$ & $14.36^{\mathrm{a}}$ & $2.43^{\mathrm{bcd}}$ & $2.51^{\mathrm{ab}}$ \\
\hline
\end{tabular}

\section{CONCLUSION}

Pre- and early post-emergence application of pendimethalin at low $(0.125 \mathrm{~kg} / \mathrm{ha})$ and high $(0.250 \mathrm{~kg} / \mathrm{ha})$ concentrations affected pod attributes differently among the five accessions of cowpea used in this study. High concentration of the herbicide applied at post-emergence increased the number of pods in TVu-9092, TVu-16265 and TVu-16421. PE and EPOE applications at low and high concentrations improved seeds weight in TVu-9092, TVu-16265 
Oladele Justina Olujuwon et al.: Effects of pendimethalin on pod attributes of five elite accessions of cowpea

and TVu-16323 while reducing the weight per pod. Pendimethalin, regardless of concentration and period of application, increased weight of empty pods in TVU-16265 and TVu-16421. The study concluded that pendimethalin application as pre- and early post-emergence herbicide at low and high concentrations produced varying effects on the pod attributes among the accessions of cowpea.

\section{ACKNOWLEDGMENT}

The authors profoundly acknowledged the Cowpea Development Unit of the International Institute of Tropical Agriculture (IITA), Ibadan, Oyo State, Nigeria, for generously provided free of cost the cowpea accessions for this study.

\section{REFERENCES}

1. Ademiluyi, B. O. and Joseph, A. (2016): Comparative evaluation of hoeweeding and pendimethalin spray regimes on weed management in cowpea (Vigna unguiculata (L) Walp.) in north central Nigeria. American Journal of Experimental Agriculture, 10(1): 1-6.

2. Akobundu, I. O. (1987): Weed control in cowpea in the humid tropics. Weed Science Journal of Nigeria, 4: 6-10.

3. Asiwe, J. A. N., Belane, A, and Dakora, F. D. (2009): Evaluation of cowpea breeding lines for nitrogen fixation at ARC-Grain Crops Institute, Potchefstroom, South Africa. Paper presented at the $16^{\text {th }}$ International Congress on Biological Nitrogen Fixation, Montana, USA, 14-19 June, 2009.

4. Chinnusamy, C., Senthil, A., Prabu Kumar, G. and Prabhakaran, N. K. (2010): Identification of threshold level of horse purslane in irrigated cowpea. Indian Journal of Weed Science, 42 (1\&2): 91-94.

5. Choudhary, S. K., Choudhary, G. L. and Prajapat, K. (2013): Response of cowpea (Vigna unguiculata (L.) Walp.) to fertility levels and mulching. Environment and Ecology, 31(2): 492-495.

6. Costa, A. F., Vale, L. S. Oliveira, A. B., Neto, J. F. B. and Cardoso, G. D. (2017): Selectivity of pre- and post-emergent herbicides for cowpea (Vigna unguiculata). African Journal of Agricultural Research, 12(11): 881-887.

7. FAO (Food and Agriculture Organization of the United Nations). (2012): World Agriculture: towards 2015/2030. Summary Report, FAO, Rome.

8. Gungula, D. T. and Garjila, Y. (2005): The effects of phosphorus application on growth and yield of cowpea in Yola. Journal of Sustainable Development in Agriculture Environment, 1(1): 96-103 
Oladele Justina Olujuwon et al.: Effects of pendimethalin on pod attributes of five elite accessions of cowpea

9. Hussaini, M. A. and Lado, A. (2010): Influence of weed control methods on yield and yield components of irrigated and rain fed cowpea [Vigna unguiculata (L.) Walp.]. Crop Research (Hisar), 40(1/3): 76-82.

10. International Institute of Tropical Agriculture (IITA) 2021a. IITA Accession 2: TVu-9 passport data. http://my.iita.org/accession2/accession/TVu-9. [Accessed May 08, 2021]

11. International Institute of Tropical Agriculture (IITA) 2021b. IITA Accession 2: $\mathrm{TVu} 16$ passport data. https://my.iita.org/accession2/accession/TVu-16. [Accessed May 08, 2021]

12. Keramati, S., Pirdashti, H., Esmali, M.A., Abbassian, A. and Habibi, M. (2008): The critical period of weed control in soybean (Glycine max L. Merr.) in North of Iran conditions. Pakistani Journal of Biological Science, 11: 463-467.

13. Khan, I. G., Hassan, M. I., Khan, M. I. and Khan, I. A. (2004): Efficacy of some new herbicidal molecules on grassy and broadleaf weeds in wheat-II. Pakistan Journal of Weed Science Research, 10: 33-38.

14. Langyintuo, A. S., Lowenberg-Deboer, J., Faye, M., et al. (2003): Cowpea supply and demand in West and Central Africa. Field Crops Research, 1(82): 215-231.

15. Li, R. G., Yumei, Z. and Zhanzhi, X. (2004): Damage loss and control technology of weeds in cowpea field. Journal of Weed Science, 2: 25-36.

16. Makinwa, R. O. and Akinyemiju, O. A. (1990): Control of Euphorbia heterophylla L. In cowpea with herbicides and herbicide mixtures. Crop Protection, 9(3): 218-224.

17. Mbata, G. N., Shu, S. and Ramaswamy, S. B. (2000): Sex pheromones of Callosobruchus subinnotatus and C. maculatus (Coleoptera: Bruchidae): congeneric responses and role of air movement. Bulletin of Entomological Research, 90: 147-154.

18. Melifonwu, A. A. (1992): Control of Mimosa invisa in maize with atrazine and its mixtures with alachlor and metalachlor. Nigerian Journal of Weed Science, 7: 9-14.

19. Muhammad, R. C., Muhammad, J. and Tahira, Z. M. (2003): Yield and yield components of cowpea as affected by various weed control methods under rain fed conditions of Pakistan. International Journal of Agriculture and Biology, 9: $120-124$.

20. Osipitan, O. A. (2017): Weed interference and control in cowpea production: A Review. Journal of Agricultural Science, 9(12): $11-20$.

21. Oyekanmi, A. A. and Sangodoyin, O. S. (2007): Evaluation of advanced lines of cowpa (Vigna unguiculata (L.) Walp) for agronomic traits and grain yield in the transition zone of Nigeria. Asian Journal of Plant Science, 6(1): 163-167. 
Oladele Justina Olujuwon et al.: Effects of pendimethalin on pod attributes of five elite accessions of cowpea

22. Patel, M. M., Patel, A. I., Patel, I. C., Tikka, S. B. S., Henry, A., Kumar, D. and Singh N. B. (2003): Weed control in cowpea under rain fed conditions. Advances in Arid Legumes Research, 4: 203-206.

23. Singh, J. T., Vivek, H. B. and Tripathi, S. S. (2004): Integrated weed management in intercropping of mungbean (Vigna radiata) and cowpea fodder (Vigna unguiculata) with pigeonpea (Cajanus cajan) under western U. P. condition. Indian Journal of Weed Science, 36: 133-134.

24. Tijani-Eniola, H. (2001): Influence of intra-rowspacing and weeding regime on the performance of cowpea (Vigna unguiculata (L) Walp). Nigerian Journal of Weed Science, 14:11-15.

25. Tripathi, S.S. and Singh, G. (2001): Critical period of weed competition in summer cowpea [Vigna unguiculata (L.) Walp.]. Indian Journal of Weed Science, 2001, 33: 67-68.

26. Ugbe, L.A., Ndaeyo, N.U. and Enyong, J.F. (2016): Efficacy of selected herbicide on weed control, cowpea (Vigna unguiculata L. Walp) performance and economic returns in Akamkpa, Southeastern Nigeria., International Journal of Research in Agriculture and Forestry, 3(5): 19-27.

27. Wadhwa, M., Bakshi, M.P.S., and Makkar, H.P.S. (2017): Utilization of empty pea (Pisum sativum) pods as livestock feed. Broadening Horizons, 46: 1-4.

28. Wadhwa, M. and M.P.S. Bakshi (2013): Utilization of fruit and vegetable wastes as livestock feed and as a substrate for generation of other value-added products. Makkar, H.P.S (Ed.). RAP Publication 2013/04, Food and Agriculture Organization of the United Nations, Rome. pp. 56.

29. World Sites Atlas (2018): Latitude and Longitude of Ilorin. https://latitude.to/map/ng/nigeria/cities/ilorin

Author's addresses - Adrese autora:

Oladele Justina Olujuwon,

Animasaun David Adedayo,

Oyedeji Stephen,

Olorunmaiye Kehinde Stephen: Correspondence author:

ksolorunmaiye@yahoo.com

Department of Plant Biology, Faculty of Life Sciences, University of Ilorin, Ilorin, Nigeria

Adekola Olabisi Fatimoh

Department of Agronomy, Faculty of Agriculture, University Ilorin, Ilorin, Nigeria 